\title{
Maternal and paternal influences on early life history traits and processes of Baltic cod Gadus morhua
}

\author{
Edward A. Trippel ${ }^{1, *}$, Gerd Kraus ${ }^{2}$, Friedrich W. Köster ${ }^{2,3}$ \\ ${ }^{1}$ Fisheries and Oceans Canada, St. Andrews Biological Station, 531 Brandy Cove Road, St. Andrews, \\ New Brunswick E5B 2L9, Canada \\ ${ }^{2}$ Leibniz Institute of Marine Sciences at Kiel University, Düsternbrooker Weg 20, 24105 Kiel, Germany \\ ${ }^{3}$ Present address: Danish Institute for Fisheries Research, Charlottenlund Castle, 2920 Charlottenlund, Denmark
}

\begin{abstract}
Embryo survival, larval standard length, yolk-sac area, yolk utilization and resistance to starvation were significantly influenced by the female parent and the interaction between both parents of Baltic Sea cod Gadus morhua in a gamete factorial cross of 3 females and 5 males in all possible combinations. The proportion of variance in embryonic survivorship that was due to maternity during incubation was significant during the first $4 \mathrm{~d}$, but was insignificant during the 5 to $9 \mathrm{~d}$ interval. During the 5 to $9 \mathrm{~d}$ interval, the male-female interaction was significant. Standard lengths at hatch and $5 \mathrm{~d}$ post hatch and specific growth rate of unfed yolk-sac larvae were strongly influenced by the female. Equivalent amounts of variation in larval resistance to starvation were explained by maternity and bi-parental interaction. Paternity alone did not explain a significant amount of variation for the traits or processes examined. The bi-parental interactions reported demonstrate a female's choice of mate could significantly influence the early life survivorship of Baltic cod offspring.
\end{abstract}

KEY WORDS: Parental effects $\cdot$ Hatch $\cdot$ Larvae $\cdot$ Growth $\cdot$ Starvation $\cdot$ Baltic cod

\section{INTRODUCTION}

In teleost fishes, the relative role of each gender in shaping early life history traits has received increasing attention in recent years (Panagiotaki \& Geffen 1992, Herbinger et al. 1995, Saillant et al. 2001, Rideout et al. 2004). Paternal factors are believed to have only limited influence, as maternal contributions via the egg are commonly cited as the chief determinants of embryonic and larval fitness (Blaxter \& Hempel 1963, Buckley et al. 1991, Keckeis et al. 2000, Marteinsdottir $\&$ Begg 2002). This restricted perspective of male influence, however, has come under increasing scrutiny (Trippel 2003, Rideout et al. 2004). Embryo survivorship has been attributed to sires in Atlantic cod Gadus morhua, with considerable range in hatching success reported of eggs of a single dam sired by multiple sires (Trippel \& Neilson 1992, Trippel \& Morgan 1994). In
Atlantic herring Clupea harengus, sperm motility was positively correlated with larval length at hatch (Evans \& Geffen 1998). Also, male effects on early life history traits have been observed in European sea bass Dicentrachus labrax (Saillant et al. 2001), brown trout Salmo trutta (Vøllestad \& Lillehammer 2000), and Alpine whitefish Coregonus sp. (Wedekind et al. 2001). In haddock Melanogrammus aeglefinus, standard length, myotome height, and jaw size of larvae were influenced to a strong degree by the sire (Rideout et al. 2004).

The mechanism by which paternal factors are manifested in the expression of phenotypic traits is presumably attributed to genetic factors. In Atlantic cod, the length of a sperm cell is $\sim 7 \mu \mathrm{m}$ and the diameter of an egg is $\sim 1500 \mu \mathrm{m}$ (Morrison 1990). The nutritional reserves and energy available for metabolism and yolk-sac larval development are solely maternal con- 
tributions, whereas both parents contribute genetically. Early life processes (e.g. efficiency of yolk utilization, embryonic development, and survivorship) are therefore potentially shaped by both sexes. Female mate choice has been associated with male body size and courtship behaviour and conceivably acts to enhance fertilization success and offspring fitness (Reynolds \& Gross 1992, Blanchfield \& Ridgway 1999, Hutchings et al. 1999).

The change in relative expression of phenotypic traits attributed to the sire and dam during early ontogeny is relevant to the temporal dynamics of progeny fitness (Saillant et al. 2001, Rideout et al. 2004). In marine fishes, studies of paternal factors that influence early life history traits have primarily examined offspring of multiple sires crossed individually with a single dam (e.g. Atlantic cod, Trippel \& Morgan 1994; herring, Evans \& Geffen 1998; and haddock, Rideout et al. 2004). None of these studies, however, were designed to accurately examine the contributions of both parents and the resulting interactions. The ability of sires to differentially influence progeny traits as a function of the dam in marine teleosts has only been examined for winter flounder Pseudopleuronectes americanus (Chambers \& Leggett 1992) and European sea bass (Saillant et al. 2001), and remains to be evaluated for gadoids, clupeids, and other flatfishes.

Our objective was to investigate, using a crossing design, the effects of both parents and their interaction on fertilization rate, hatching rate, larval traits, yolk utilization and growth of Baltic cod during the nonfeeding phase under standardized conditions.

\section{MATERIALS AND METHODS}

On August 8, 2001, Baltic cod were collected from the Bornholm Basin, Central Baltic Sea, by the RV 'Alkor' using a semi-pelagic otter trawl with slow haul times. Total length and body weight were recorded for each fish caught. Specimens were hand stripped and gametes specific to 5 males and 3 females were uniquely stored in covered beakers and maintained in a constant temperature room $\left(4^{\circ} \mathrm{C}\right)$. So that gamete quality was not compromised (Kjørsvik \& Lønning 1983, Trippel 2003), fish collection was conducted such that sperm were used for crosses within $8 \mathrm{~h}$ and eggs within $4 \mathrm{~h}$ of collection. Sperm of 5 males were separately added to eggs with each cross-replicated 5 times to generate 75 crosses. Fertilization was conducted by adding $0.2 \mathrm{ml}$ of sperm to 350-450 eggs and gently mixing with a glass rod; $50 \mathrm{ml}$ filtered seawater was then added, swirled, allowed to stand for $1 \mathrm{~min}$ and the eggs added to a $500 \mathrm{ml}$ plastic incubator containing filtered seawater. Dry fertilization was used to maximize fertilization rate thereby producing as great a number of embryos as possible from the supply of stripped eggs (assessment of fertilization rate under diluted sperm concentration was not an objective of the experiment). Gamete mixing procedures to create the 75 crosses were completed in $30 \mathrm{~min}$ and were performed in a random sequence with regard to family. After $24 \mathrm{~h}$, eggs were removed by filtering through a $1 \mathrm{~mm}$ mesh screen and placed in a Petrie dish for enumeration and assessment of fertilization rate. Eggs of each of the 75 crosses were filmed using a video camera. The diameters of 60 fertilized eggs of each female were recorded using the image analysis program NIH-Image (available at http://rsb.info.nih.gov/nih-image/). Unfertilized eggs were identified as having no cell cleavage and containing a central germ cell. Eggs characterized by an opaque dark centre were classified as non-viable and excluded from assessment of fertilization and amounted to $\sim 5 \%$ of total eggs of each female used. Fertilized (16 cell stage and greater) and unfertilized eggs were enumerated and the fertilized eggs were placed in a $500 \mathrm{ml}$ plastic incubator containing fresh filtered seawater for further incubation and stored in random order in a cold temperature room at $4^{\circ} \mathrm{C}$.

Incubators were checked daily and dead embryos removed by syringe. These were identified by being white and opaque and resting on the incubator bottom. Care was taken not to remove live embryos which occasionally were also on the incubator bottom. Water exchange $(\sim 75 \%)$ was made every second day until hatching by siphoning out water using a tube covered with a $1 \mathrm{~mm}$ Nitex mesh. From daily mortalities, embryo survival for the early (Days 0 to 4), mid (Days 5 to 9) and late embryonic phases (percentage of larvae emerging from viable eggs remaining just prior to hatching; Day 9 to hatch) was estimated. On August 19, the RV 'Alkor' returned to the Leibniz Institute of Marine Sciences and incubators were moved to a cold room and maintained at $4^{\circ} \mathrm{C}$ until hatching in the same incubators. Hatching success was defined as the percentage of fertilized eggs from which larvae hatched (Day 0 hatch).

At hatch, 20 larvae of each cross were videotaped at $16 \times$ magnification. Larvae were removed from the incubators and placed in well slides with an image of each larva's side view recorded for subsequent morphometric measurements (Thorsen et al. 2003). A video counter enabled the unique identification of recorded images of each larva. Videotaping of Day 0 larva occurred in a random order. Approximately 20 Day 0 larvae were placed into $15 \mathrm{ml}$ dishes for monitoring of time to starvation. Water exchange $(\sim 75 \%)$ was made every second day with no decline in oxygen concentration noted (>95\% saturation). Dishes were arranged randomly in the coldroom $\left(4^{\circ} \mathrm{C}\right)$, checked 
daily and dead larvae identified by their shrivelled state and absence of a heartbeat. After further larval development from endogenous sources, Day 5 larvae were videotaped. Images of Day 0 and Day 5 larvae were analysed. Larval standard length (SL) and yolksac area (YA) were assessed for 20 larvae of each family replicate of each age using NIH-image. Yolk utilization rate was calculated as the difference in YA from Day 0 to Day 5 divided by YA on Day 0. Yolk utilization efficiency was calculated by dividing the increase in SL from Day 0 to Day 5 by the corresponding decrease in YA (modified after Rideout et al. 2004).

Statistical analyses were carried out using the Statistica software (Statistica 6.1, StatSoft). For all data the fundamental ANOVA assumptions were tested. In order to meet ANOVA assumptions of homogeneity of variances and normal distribution, data on fertilization rate, hatching success, egg survival, daily specific growth rate (SGR) and yolk utilization rate were arcsine transformed, data on yolk utilization efficiency were log transformed, and those on time to starvation were power transformed. SL and YA needed no transformation. Normal distribution was tested by Kolmogorov-Smirnov tests on $z$-transformed data pooled over all families due to low sample sizes per family (5 replicates). Homogeneity of variance was checked by Hartley's F-max and Bartlett chi-square tests. ANOVAs were conducted on the means of the 5 replicates for each cross (e.g. Saillant et al. 2001, Rideout et al. 2004). In this way, the true experimental units, the 3 female and 5 male parental cod, were used and pseudoreplication was avoided.

Different types of ANOVA designed to account for unequal sample sizes were applied to resolve the significance of maternal, paternal and interaction effects. For each trait measured on Day 0 and Day 5, a mixed model 2-way repeated measures ANOVA was performed. In case of significant first order interaction between day and female or male, two separate model II 2-way ANOVAs were performed to resolve parental effects on early life history traits. Corresponding to the second analysis step, for all other traits model II 2way ANOVAs were performed to detect significant maternal, paternal and sire-dam interaction effects. Significance for main effects was set at $p=0.05$. Detection of a significant interaction was set at $p=$ 0.20 to minimize the potential for a type II error (Winer 1971, p. 379).

\section{RESULTS}

Length and body weight of the 3 females and 5 males used in experimental crosses are given in Table 1. Mean egg diameters for Females 1 to 3 were $1.630 \mathrm{~mm}$
$(\mathrm{SE}=0.003), 1.648 \mathrm{~mm}(\mathrm{SE}=0.003)$, and $1.676 \mathrm{~mm}$ $(\mathrm{SE}=0.005)$, respectively, and differed significantly among females (ANOVA, $F=34.1, \mathrm{p}<0.001$ ). Mean fertilization rates were high and ranged between 96.2 and $98.9 \%$. Differences were significant among females as was the sire-dam interaction term at the 0.20 level (Table 2). No clear pattern explained the interaction, but differences in mean fertilization rates among females were larger than among males. Family average embryo losses during the first $4 \mathrm{~d}$ post fertilization were high and ranged from $65 \%$ in Female 2 to $30 \%$ in Female 1 (Fig. 1a). Early embryo survival was significantly influenced by sire-dam interaction $(7.6 \%$ of explained variance) and maternity $(74.1 \%$ of explained variance; Table 2). No clear tendency explained the interaction effect (Fig. 1a).

During the mid phase (Days 5 to 9) losses decreased considerably, ranging from 14.3 to $18.8 \%$, with the differences in survival rates among the 3 females declining (Fig. 1b). Compared to the early period, the interaction term explained $32.8 \%$ (vs. $7.6 \%$ ), whereas independently dam and sire did not contribute at all. Losses during the late phase (Day 9 to hatch), defined as the proportion of hatched larvae from the number of viable embryos before the start of hatching, ranged from 15.4 to $21.6 \%$ (Fig. 1c). Only female effects were significant during this late embryonic phase $(58.0 \%$ vs. $74.1 \%$ explained variation during Days 0 to 4 ). Overall survival from fertilization to hatching was reflected in hatching success, which was highest in Female 1 $(60.3 \%)$, intermediate in Female $2(42.6 \%)$ and lowest in Female $3(31.0 \%)$ (Fig. 1d), with only significant maternal effects evident (Table 2).

Mean SL of Day 0 larvae for Females 1 to 3 were $3.44,3.75$, and $3.86 \mathrm{~mm}$ and mean YA ranged from $1.70,1.74$ to $1.66 \mathrm{~mm}^{2}$, respectively (Figs. $2 \& 3$ ). Two factorial mixed model repeated measures ANOVAs of SL and YA revealed significant first order interaction of dam and sire $\times$ day $(p<0.01)$. Thus, separate model 2 ANOVAs were performed for Day 0 and Day 5 measurements. SL and YA of Day 0 were significantly

Table 1. Gadus morhua. Total length and body weight of individuals used in experimental crosses

\begin{tabular}{|lcc|}
\hline & Total length $(\mathrm{cm})$ & Body weight $(\mathrm{g})$ \\
\hline Female 1 & 48 & 1190 \\
Female 2 & 49 & 1020 \\
Female 3 & 54 & 1525 \\
Male 1 & 47 & 815 \\
Male 2 & 42 & 580 \\
Male 3 & 40 & 500 \\
Male 4 & 22 & 65 \\
Male 5 & 37 & 360 \\
\hline
\end{tabular}


Table 2. Gadus morhua. Maternal, paternal, and bi-parental influences (i.e. interaction terms) on early life history traits and processes of Baltic cod, as shown by their percent relative contribution to explained variance in 2-way ANOVAs. df: degrees of freedom, SS: sum squares, MS: mean squares, $F$ and p: critical values and probability of significance tests, SL: standard length, YA: yolk area, and SGR: specific growth rate

\begin{tabular}{|c|c|c|c|c|c|c|c|}
\hline Response & Source & $\mathrm{df}$ & SS & MS & $F$ & $\mathrm{p}$ & $\begin{array}{c}\text { Relative } \\
\text { contribution (\%) }\end{array}$ \\
\hline $\begin{array}{l}\text { Fertilization } \\
\text { rate }\end{array}$ & $\begin{array}{c}\text { Female } \\
\text { Male } \\
\text { Interaction } \\
\text { Error }\end{array}$ & $\begin{array}{c}2 \\
4 \\
8 \\
60\end{array}$ & $\begin{array}{r}463.02 \\
17.06 \\
47.08 \\
244.07\end{array}$ & $\begin{array}{r}231.51 \\
4.26 \\
5.88 \\
4.07\end{array}$ & $\begin{array}{r}39.34 \\
0.72 \\
1.45\end{array}$ & $\begin{array}{r}<0.01 \\
0.60 \\
0.20\end{array}$ & $\begin{array}{r}67.1 \\
0.0 \\
2.7 \\
30.2\end{array}$ \\
\hline $\begin{array}{l}\text { Egg survival } \\
\text { Days } 0-4\end{array}$ & $\begin{array}{c}\text { Female } \\
\text { Male } \\
\text { Interaction } \\
\text { Error }\end{array}$ & $\begin{array}{c}2 \\
4 \\
8 \\
60\end{array}$ & $\begin{array}{r}4164.55 \\
94.86 \\
491.72 \\
1193.39\end{array}$ & $\begin{array}{r}2082.27 \\
23.72 \\
61.47 \\
19.89\end{array}$ & $\begin{array}{r}33.88 \\
0.39 \\
3.09\end{array}$ & $\begin{array}{r}<0.01 \\
0.81 \\
0.01\end{array}$ & $\begin{array}{r}74.1 \\
0.0 \\
7.6 \\
18.2\end{array}$ \\
\hline $\begin{array}{l}\text { Egg survival } \\
\text { Days } 5-9\end{array}$ & $\begin{array}{c}\text { Female } \\
\text { Male } \\
\text { Interaction } \\
\text { Error }\end{array}$ & $\begin{array}{c}2 \\
4 \\
8 \\
60\end{array}$ & $\begin{array}{r}407.85 \\
71.22 \\
976.90 \\
1988.44\end{array}$ & $\begin{array}{r}203.92 \\
17.81 \\
122.11 \\
33.14\end{array}$ & $\begin{array}{l}1.67 \\
0.15 \\
3.68\end{array}$ & $\begin{array}{r}0.25 \\
0.96 \\
<0.01\end{array}$ & $\begin{array}{r}6.0 \\
0.0 \\
32.8 \\
61.1\end{array}$ \\
\hline $\begin{array}{l}\text { Embryos } \\
\text { hatched } \\
\text { Day 9-hatch }\end{array}$ & $\begin{array}{c}\text { Female } \\
\text { Male } \\
\text { Interaction } \\
\text { Error }\end{array}$ & $\begin{array}{c}2 \\
4 \\
8 \\
60\end{array}$ & $\begin{array}{r}62.54 \\
3961.59 \\
338.96 \\
3364.28\end{array}$ & $\begin{array}{r}15.64 \\
1980.79 \\
42.37 \\
56.07\end{array}$ & $\begin{array}{r}0.37 \\
46.75 \\
0.76\end{array}$ & $\begin{array}{r}0.82 \\
<0.01 \\
0.64\end{array}$ & $\begin{array}{r}58.0 \\
0.0 \\
0.0 \\
42.0\end{array}$ \\
\hline $\begin{array}{l}\text { Hatching } \\
\text { success } \\
\text { Day 0-hatch }\end{array}$ & $\begin{array}{c}\text { Female } \\
\text { Male } \\
\text { Interaction } \\
\text { Error }\end{array}$ & $\begin{array}{c}2 \\
4 \\
8 \\
58\end{array}$ & $\begin{array}{r}676.29 \\
213.56 \\
282.04 \\
2477.80\end{array}$ & $\begin{array}{r}338.14 \\
53.39 \\
35.26 \\
42.72\end{array}$ & $\begin{array}{l}9.59 \\
1.51 \\
0.83\end{array}$ & $\begin{array}{l}0.01 \\
0.29 \\
0.58\end{array}$ & $\begin{array}{r}22.1 \\
2.2 \\
0.0 \\
75.6\end{array}$ \\
\hline SL Day 0 & $\begin{array}{c}\text { Female } \\
\text { Male } \\
\text { Interaction } \\
\text { Error }\end{array}$ & $\begin{array}{c}2 \\
4 \\
8 \\
54\end{array}$ & $\begin{array}{l}2.17 \\
0.06 \\
0.11 \\
0.44\end{array}$ & $\begin{array}{l}1.09 \\
0.01 \\
0.01 \\
0.01\end{array}$ & $\begin{array}{r}80.61 \\
1.09 \\
1.67\end{array}$ & $\begin{array}{r}<0.01 \\
0.42 \\
0.13\end{array}$ & $\begin{array}{r}83.5 \\
0.2 \\
2.1 \\
14.2\end{array}$ \\
\hline SL Day 5 & $\begin{array}{c}\text { Female } \\
\text { Male } \\
\text { Interaction } \\
\text { Error }\end{array}$ & $\begin{array}{c}2 \\
4 \\
8 \\
53\end{array}$ & $\begin{array}{l}0.12 \\
0.05 \\
0.05 \\
0.39\end{array}$ & $\begin{array}{l}0.06 \\
0.01 \\
0.01 \\
0.01\end{array}$ & $\begin{array}{l}9.82 \\
1.94 \\
0.81\end{array}$ & $\begin{array}{r}<0.01 \\
0.19 \\
0.59\end{array}$ & $\begin{array}{r}25.8 \\
4.4 \\
0.0 \\
69.8\end{array}$ \\
\hline YA Day 0 & $\begin{array}{c}\text { Female } \\
\text { Male } \\
\text { Interaction } \\
\text { Error }\end{array}$ & $\begin{array}{c}2 \\
4 \\
8 \\
56\end{array}$ & $\begin{array}{l}0.54 \\
0.05 \\
0.16 \\
0.59\end{array}$ & $\begin{array}{l}0.27 \\
0.01 \\
0.02 \\
0.01\end{array}$ & $\begin{array}{r}13.55 \\
0.60 \\
1.90\end{array}$ & $\begin{array}{r}<0.01 \\
0.67 \\
0.08\end{array}$ & $\begin{array}{r}49.7 \\
0.0 \\
4.3 \\
46.0\end{array}$ \\
\hline YA Day 5 & $\begin{array}{c}\text { Female } \\
\text { Male } \\
\text { Interaction } \\
\text { Error }\end{array}$ & $\begin{array}{c}2 \\
4 \\
8 \\
53\end{array}$ & $\begin{array}{l}2.35 \\
0.41 \\
0.26 \\
1.60\end{array}$ & $\begin{array}{l}1.18 \\
0.10 \\
0.03 \\
0.03\end{array}$ & $\begin{array}{r}36.78 \\
3.22 \\
1.06\end{array}$ & $\begin{array}{r}<0.01 \\
0.07 \\
0.40\end{array}$ & $\begin{array}{r}61.2 \\
6.1 \\
0.4 \\
32.2\end{array}$ \\
\hline Daily SGR & $\begin{array}{c}\text { Female } \\
\text { Male } \\
\text { Interaction } \\
\text { Error }\end{array}$ & $\begin{array}{c}2 \\
4 \\
8 \\
52\end{array}$ & $\begin{array}{r}388.08 \\
39.34 \\
60.33 \\
282.65\end{array}$ & $\begin{array}{r}194.04 \\
9.83 \\
7.54 \\
5.44\end{array}$ & $\begin{array}{r}25.94 \\
1.31 \\
1.39\end{array}$ & $\begin{array}{r}<0.01 \\
0.34 \\
0.22\end{array}$ & $\begin{array}{r}59.1 \\
1.2 \\
3.2 \\
36.4\end{array}$ \\
\hline $\begin{array}{l}\text { Yolk } \\
\text { utilization } \\
\text { rate }\end{array}$ & $\begin{array}{c}\text { Female } \\
\text { Male } \\
\text { Interaction } \\
\text { Error }\end{array}$ & $\begin{array}{c}2 \\
4 \\
8 \\
52\end{array}$ & $\begin{array}{r}592.12 \\
85.53 \\
111.70 \\
378.73\end{array}$ & $\begin{array}{r}296.06 \\
21.38 \\
13.96 \\
7.28\end{array}$ & $\begin{array}{r}21.50 \\
1.55 \\
1.92\end{array}$ & $\begin{array}{r}<0.01 \\
0.28 \\
0.08\end{array}$ & $\begin{array}{r}58.7 \\
2.6 \\
6.7 \\
32.0\end{array}$ \\
\hline $\begin{array}{l}\text { Yolk } \\
\text { utilization } \\
\text { efficiency }\end{array}$ & $\begin{array}{c}\text { Female } \\
\text { Male } \\
\text { Interaction } \\
\text { Error }\end{array}$ & $\begin{array}{c}2 \\
4 \\
8 \\
52\end{array}$ & $\begin{array}{l}6.87 \\
0.71 \\
0.55 \\
1.86\end{array}$ & $\begin{array}{l}3.43 \\
0.18 \\
0.07 \\
0.04\end{array}$ & $\begin{array}{r}52.27 \\
2.68 \\
1.84\end{array}$ & $\begin{array}{r}<0.01 \\
0.10 \\
0.09\end{array}$ & $\begin{array}{r}76.7 \\
4.1 \\
3.3 \\
16.0\end{array}$ \\
\hline $\begin{array}{l}\text { Time to } \\
\text { starvation }\end{array}$ & $\begin{array}{c}\text { Female } \\
\text { Male } \\
\text { Interaction } \\
\text { Error }\end{array}$ & $\begin{array}{c}2 \\
4 \\
8 \\
50\end{array}$ & $\begin{array}{l}34816.21 \\
31059.10 \\
31089.83 \\
68980.22\end{array}$ & $\begin{array}{r}17408.10 \\
7764.78 \\
3886.23 \\
1379.60\end{array}$ & $\begin{array}{l}4.55 \\
2.08 \\
2.82\end{array}$ & $\begin{array}{l}0.05 \\
0.17 \\
0.01\end{array}$ & $\begin{array}{l}22.4 \\
11.5 \\
20.2 \\
45.9\end{array}$ \\
\hline
\end{tabular}



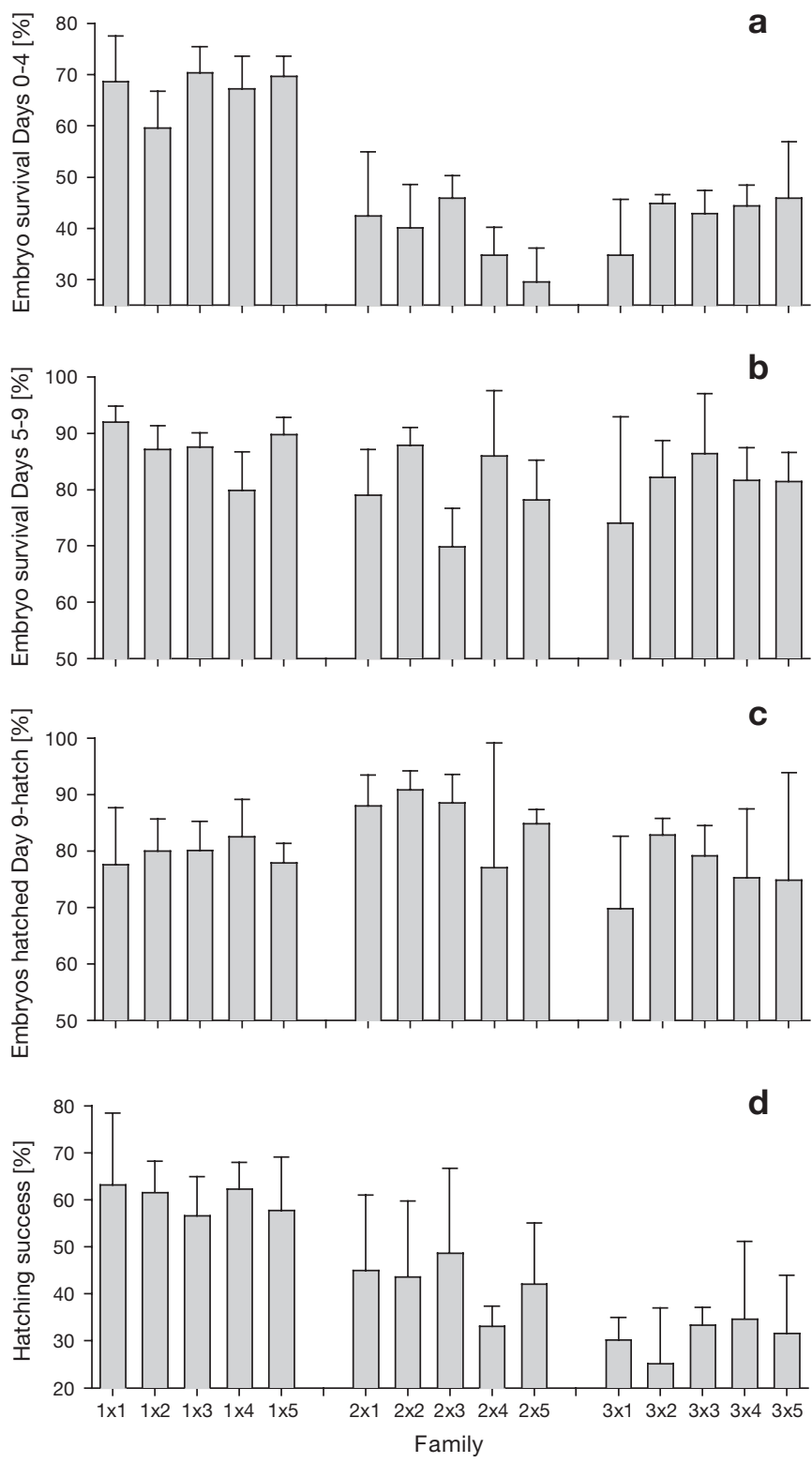

Fig. 1. Gadus morhua. (a,b) Embryo survival during the early and intermediate incubation phase defined as Days 0-4 and Days 5-9 d post fertilization, respectively. (c) Late embryonic phase, represented by the number of larvae hatched from viable embryos just prior to onset of the hatching period (Day 9 to hatch). (d) Hatching success defined as percentage of embryos hatching from fertilized eggs. Error bars are $+1 \mathrm{SD}$

influenced by maternity, but no sire effect could be detected. However, this observation may be influenced by a significant sire-dam interaction at the 0.20 level for SL and at the 0.10 level for YA. Variation explained by maternity in SL declined from 83.5 to $25.8 \%$ from Day 0 to Day 5 concurrent with a strong increase in residual variance, while maternally explained variance in YA increased from 49.7 to $61.2 \%$

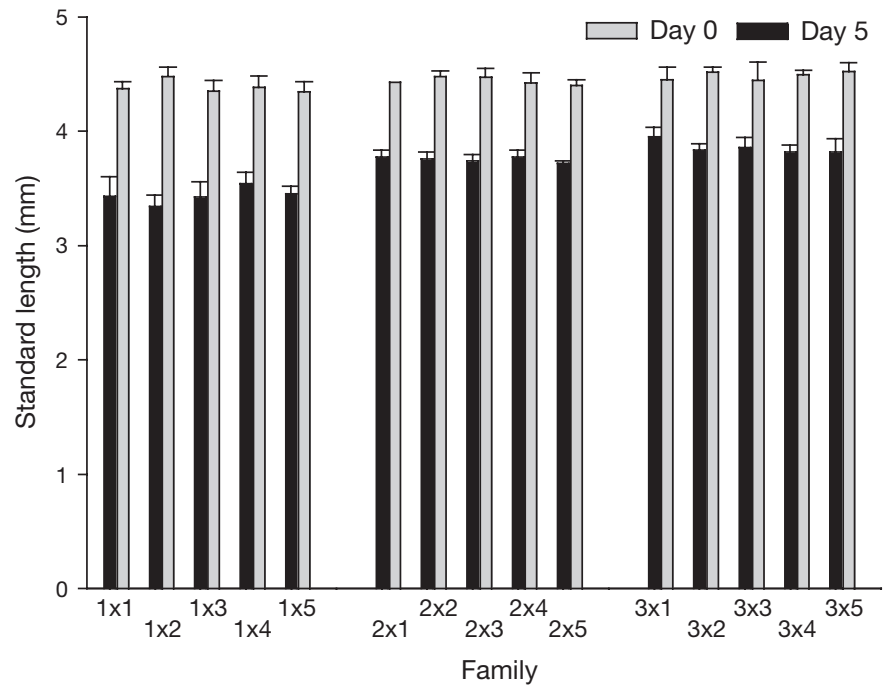

Fig. 2. Gadus morhua. Standard length of newly hatched and Day 5 larvae displayed as family means. Error bars represent 1 SD multiplied by 3

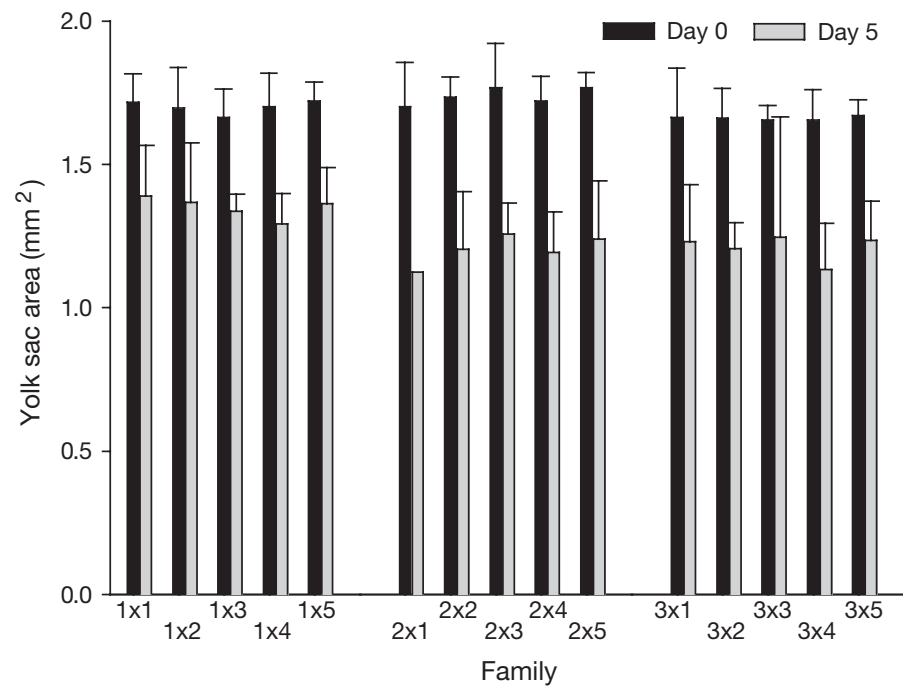

Fig. 3. Gadus morhua. Yolk-sac area of newly hatched and Day 5 larvae displayed as family means. Error bars represent $1 \mathrm{SD}$ multiplied by 3

during this period (Table 2). Interaction terms for both SL and YA were not significant, while the sire contribution to explained variance for YA was nearly significant $(\mathrm{p}=0.07)$.

Maternity significantly affected daily SGR of larvae from hatch to Day 5, explaining $59.1 \%$ of variation (Table 2, Fig. 4). Paternity and sire-dam interaction were not significant for SGR. However, the sire-dam interactions were significant for yolk utilization rate (6.7\% explained variation; $\mathrm{p}=0.08)$ and yolk utilization efficiency ( $3.3 \%$ explained variation; $p=0.09)$, but 


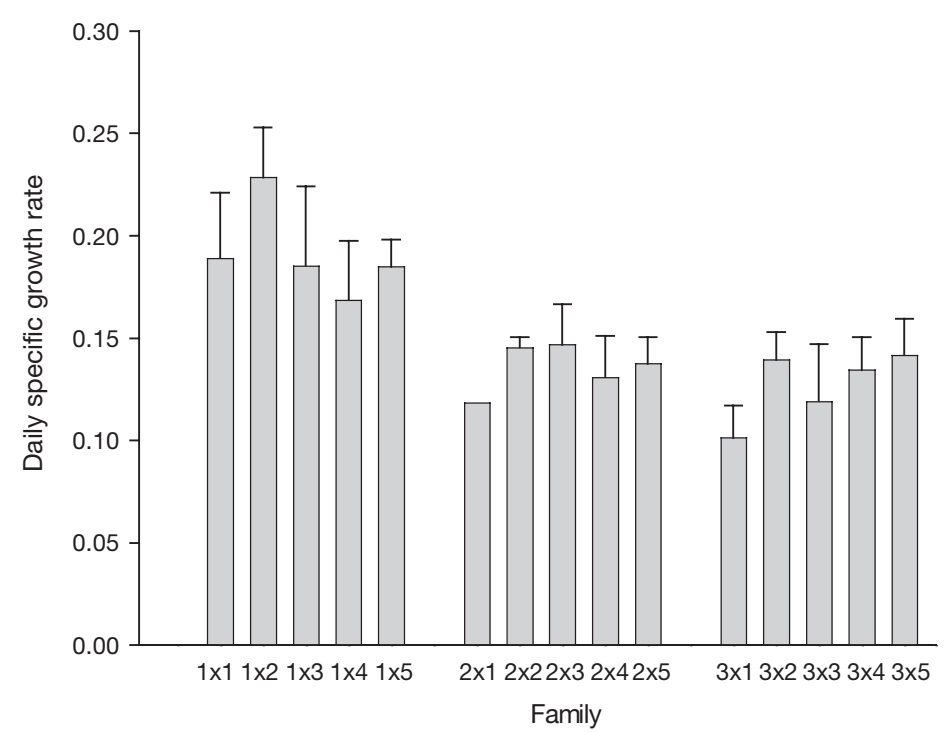

Fig. 4. Gadus morhua. Daily specific growth rate of larvae calculated as mean rates over the first $5 \mathrm{~d}$ post hatch. Error bars are $+1 \mathrm{SD}$

in the latter case the ANOVA assumption of homoscedasticity was slightly violated (Levene-test, $\mathrm{p}=$ 0.03). The amounts of variation explained by maternity in yolk utilization rate and yolk utilization efficiency were 58.7 and $76.7 \%$, respectively, and were comparatively high when compared to the parental interactions (Table 2, Fig. 5).

Time to starvation expressed as days to $50 \%$ dead among 15 families ranged from 4.94 to $8.70 \mathrm{~d}$, and mean times to starvation for Females 1 to 3 were 7.15 ,

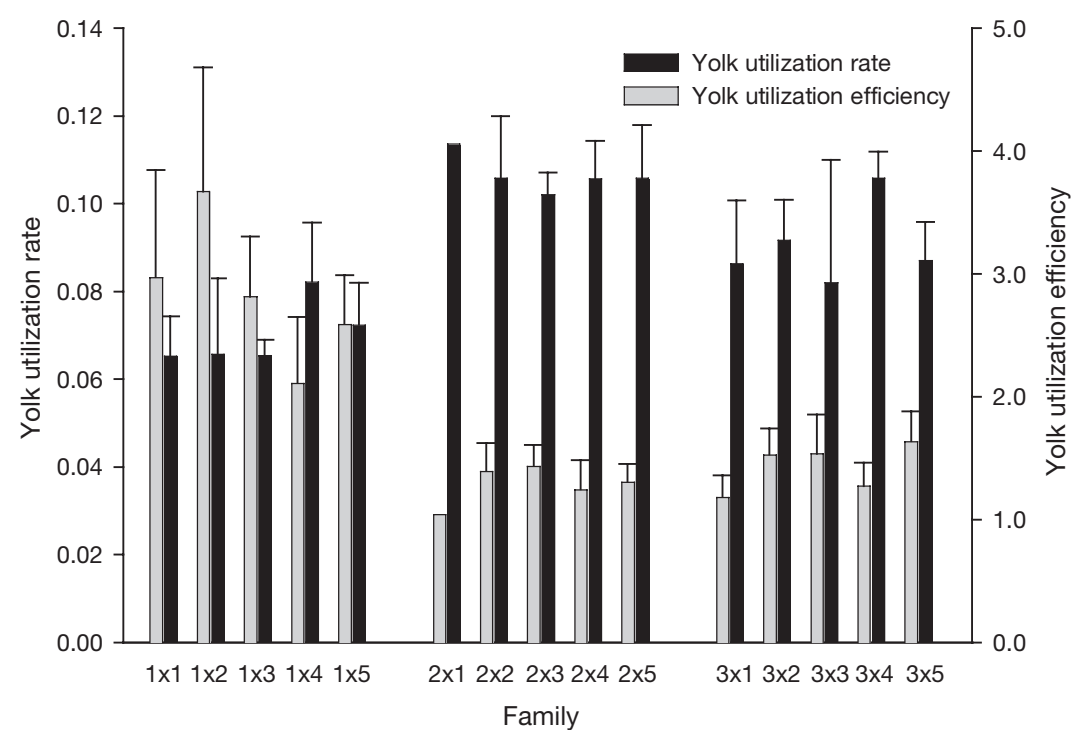

Fig. 5. Gadus morhua. Daily yolk utilization efficiency of larvae calculated as mean rates over the first $5 \mathrm{~d}$ post hatch. Error bars are $+1 \mathrm{SD}$

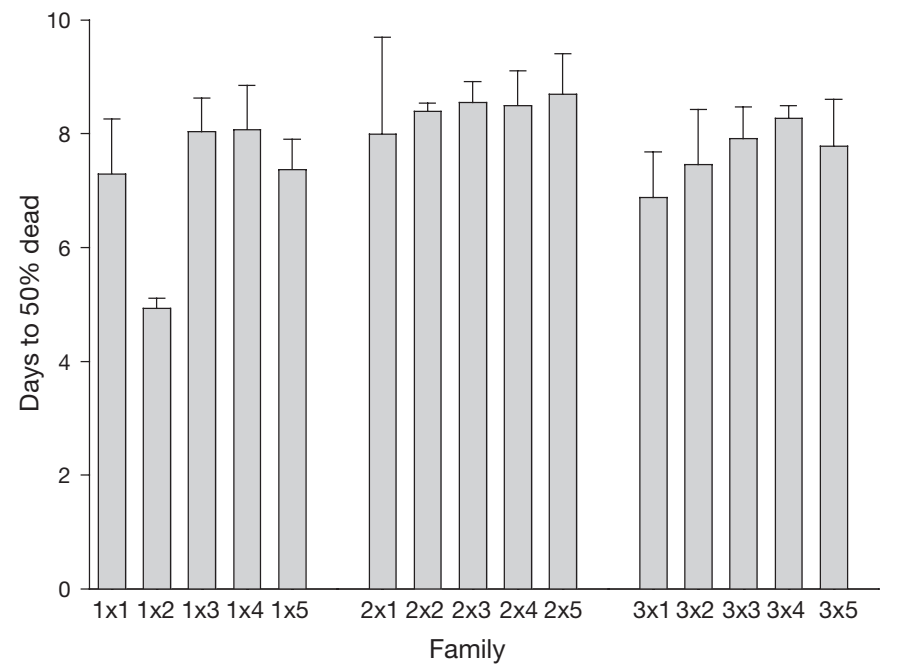

Fig. 6. Gadus morhua. Time to starvation of larvae calculated as family mean days to $50 \%$ dead. Error bars are $+1 \mathrm{SD}$

8.46, and 7.66 d, respectively (Fig. 6). Of all response variables, time to starvation was most strongly influenced by parental interaction $(20.2 \%$ of explained variance; $\mathrm{p}<0.01$ ), and was also notably influenced by maternity (Table 2). The low resistance to starvation of progeny of Female 1 and Male 2 was a major contributing factor underlying this significant interaction (Fig. 6)

\section{DISCUSSION}

As noted by Brooks et al. (1997), studies on genetic influences on egg quality need to take into account the 'male' factor, as the genes from the males will influence embryonic performance and thus the perceived 'egg quality'. In our experiment, parental influences varied in their relative importance during different stages of embryogenesis. Female effects were greatest during early and late embryonic development, and the male-female interaction dominated the mid embryonic stage. Our temporal partitioning of losses during embryonic development permitted detection of this dam-sire interaction, which went undetected when using the traditional measure of hatching success. Examination of changes in 
sex-specific influences on survival over the course of incubation is rarely undertaken (Wedekind et al. 2001). Sire breeding ornamentation was positively correlated with bacterial resistance of embryos in Alpine whitefish, such that strongly ornamented males sired offspring that better survived the epidemic during late embryonic development (Wedekind et al. 2001). In contrast, during early embryonic mortality (characterized by developmental abnormalities) male-female interactions were significant. These results on Alpine whitefish suggest that genetic components may be involved in the survival performance during this last phase of embryonic development, and that the parental contributions are not simply additive but mainly interactive. A similar interpretation can be applied to Baltic cod life history stages where significant parental interaction occurred. In general, however, only a moderate influence of bi-parental interaction was observed in our study which did not increase with ontogeny.

The minor variation in fertilization rates we observed were primarily regulated by the dam, as sperm concentration during fertilization was very high, though presumably if seawater-diluted semen mixtures or brief egg-sperm interaction times had been used, fertilization would have been under greater sire control (Rosenthal et al. 1988, Westin \& Nissling 1991, Trippel 2003). Kjørsvik \& Lønning (1983) noted that maternal factors such as egg quality controlled early development $(28 \mathrm{~h})$ of half-siblings generated from 6 female cod inseminated by sperm from each of 2 males. We noted that early survival (Days 0 to 4 ) was primarily under maternal control in Baltic cod.

Female effects dominated a number of other traits and processes, including SL, YA, and yolk usage by the progeny (i.e. depletion rate and amount used to develop new tissue). Paternal effects in our study were only revealed through interaction with respective females, and did not solely contribute to explaining variability in early life history. Interestingly, in haddock, male effects had a larger impact on these traits (Rideout et al. 2004), as in their study the female effect was not significant for Days 0 to 10 , but the effect of sire on length declined (54.1, 35.7 to $18.1 \%$ for Days 0, 5 and 10, respectively). In European sea bass, the parental effects were assessed from a complete factorial crossing between 7 females and 6 males. The males had an influence equivalent to those of females on hatching success, but they only acted via interaction on egg fertilization rate, egg survival and on larval growth during the endotrophic phase. Chambers \& Leggett (1992) reported no male effect on size at metamorphosis in winter flounder. Reported variable importance of maternal and paternal effects on fish early life history is presumably manifested in (1) differ- ing egg sizes among females which affect $\mathrm{YA}, \mathrm{SL}$, etc. (Blaxter \& Hempel 1963, Pickova et al. 1997, Trippel 1998), (2) genetic heterogeneity among dams and sires and their compatibility in improving fitness of traits when crossed (Tregenza \& Wedell 2000, Kokko 2001), and (3) the small number of fish $(<20)$ typically used in crosses. These 3 factors could account for the mixed results obtained among experimental studies to date that have ascribed relative variability in early life history traits and processes to parental gender.

The results for Baltic cod and those for other species demonstrate that investigators should be cautious when using sperm pooled from several males in experimental crosses to test the effects of environmental factors (e.g. temperature, salinity, light and food supply) on early life history stages. Unequal fathering of offspring by males (Gile \& Ferguson 1995, Rakitin et al. 1999) could lead to an unbalanced abundance of various progeny genotypes in replicates that react differently to environmental factors, contributing greater error in statistical analyses when assessing the effects of abiotic factors on progeny traits and performance (Pepin et al. 1997, Trippel 2003).

The ability of newly feeding larvae to withstand prolonged periods of food deprivation in the wild is significant for species such as cod that inhabit environments with variable zooplankton abundance (Mertz \& Myers 1994, Möllmann et al. 2003). Specifically, Hinrichsen et al. (2003) have shown that the abundance of Pseudocalanus spp. is crucial for survival of larval Baltic cod. Attributes of egg size and quality are commonly cited to influence starvation rates and early growth of larvae (Knutsen \& Tilseth 1985, Hutchings 1991, Marteinsdottir \& Steinarsson 1998). In our study of larval resistance to starvation, the male-female interaction term was equivalent to the female effect $(20.2$ and $22.4 \%$, respectively). Consequently, survival of a progeny of a female can be significantly influenced by the male parent (note in particular Male 2, Fig. 6). Increased attention to the relative role of each gender in governing early life performance is required to more fully understand the parental factors responsible for variable survivorship and recruitment (Köster et al. 2003). Paternal effects for growth rate and life span of unfed larvae of brown trout Salmo trutta have also been reported (Vøllestad \& Lillehammer 2000). Early maternal effects can be due to environmental (yolk reserves are mainly controlled by food intake during oogenesis) and genetic factors. Genetic effects are more easily studied using a large number of males fertilizing 1 or a few females (i.e. trying to keep the maternal effect constant) as the paternal contribution is restricted to nuclear genetic material.

Further research is required to assess paternal characteristics influencing offspring growth and survivor- 
ship in captivity and in the wild, as genetic effects attributed to males presumably operate throughout ontogeny (Herbinger et al. 1995, Clemmesen et al. 2003). In our study, too few males were used to evaluate if any adult phenotypic characteristics were correlated with offspring characteristics (Wedell \& Tregenza 1999). It is of interest, however, that a small male $(22 \mathrm{~cm})$ was able to sire larvae of comparable quality to the other males.

Understanding the causes of embryonic and larval mortalities in cod stocks is significant to elucidating the recruitment mechanisms in this commercially important species. Given that the complex mating system of cod involves female mate choice and promiscuous spawning (Hutchings et al. 1999, Rakitin et al. 2001, Bekkevold et al. 2002), the results of our study on Baltic cod revealed the potential variability in fitness of progeny generated among parental matings that may occur among naturally spawning cod. A single female spawning with 3 or 4 males during one act may generate progeny with a broad suite of phenotypes, which differ in growth and survivorship potential. Females are highly fecund and mate numerous times during a lengthy spawning period (Kjesbu 1989, Trippel 1998), presumably with a different set of males each time. Therefore, each year a female cod has the potential to generate half-siblings of a broad genetic composition that vary in fitness in early life. Further assessment of paternal relative to maternal factors (genetic and phenotypic) that potentially contribute to the expression of morphological traits and early life processes in marine fishes is warranted.

Acknowledgements. We appreciate the field assistance of R. Lüthje during the collection of fish and production of crosses aboard the RV 'Alkor'. Measurement of morphometric traits was assisted by N. Probst, A. Malzahn, A. Huber and C. Clemmesen. We thank D. Schnack for his comments on statistical aspects and R. Rideout, T. Shepherd and 3 anonymous referees for their valuable comments on the manuscript. This project was funded in part by the Canada/Germany Bilateral Cooperation in Science and Technology, the Leibniz Institute of Marine Sciences at Kiel University, and Fisheries and Oceans Canada.

\section{LITERATURE CITED}

Bekkevold D, Hansen MM, Loeschcke V (2002) Male reproductive competition in spawning aggregations of cod (Gadus morhua L.). Mol Ecol 11:91-102

Blanchfield PJ, Ridgway MS (1999) The cost of peripheral males in a brook trout mating system. Anim Behav 57:537-544

Blaxter JHS, Hempel G (1963) The influence of egg size on herring larvae (Clupea harengus L.). J Cons Perm Int Explor Mer 28:211-240

Brooks S, Tyler CR, Sumpter P (1997) Egg quality in fish: What makes a good egg? Rev Fish Biol Fish 7:321-330
Buckley LJ, Smigielski AS, Halavik TA, Caldarone EM, Burns BR, Laurence GC (1991) Winter flounder Pseudopleuronectes americanus reproductive success. II. Effects of spawning time and female size on size, composition and viability of eggs and larvae. Mar Ecol Prog Ser 74:125-135

Chambers RC, Leggett WC (1992) Possible causes and consequences of variation in age and size at metamorphosis in flatfishes (Pleuronectiformes): an analysis at the individual, population, and species level. Neth J Sea Res 29:7-24

Clemmesen C, Bühler V, Carvalhao G, Case R and 10 others (2003) Variability in condition and growth of Atlantic cod larvae and juveniles reared in mesocosms: environmental and maternal effects. J Fish Biol 62:706-723

Evans JP, Geffen AJ (1998) Male characteristics, sperm traits, and reproductive success in winter-spawning Celtic Sea Atlantic herring, Clupea harengus. Mar Biol 132:179-186

Gile SR, Ferguson MM (1995) Factors affecting male potency in pooled gamete crosses of rainbow trout (Oncorhynchus mykiss). Environ Biol Fish 42:267-275

Herbinger CM, Doyle RW, Pitman ER, Paquet D, Mesa KA, Morris DB, Wright JM, Cook D (1995) DNA fingerprint based analysis of paternal and maternal effects on offspring growth and survival in communally reared rainbow trout. Aquaculture 137:245-256

Hinrichsen HH, Lehmann A, Möllmann C, Schmidt JO (2003) Dependency of larval fish survival on retention/dispersion in food limited environments: The Baltic Sea as a case study. Fish Oceanogr 12:425-433

Hutchings JA (1991) Fitness consequences of variation in egg size and food abundance in brook trout, Salvelinus fontinalis. Evolution 45:1162-1168

Hutchings JA, Bishop TD, McGregor-Shaw CR (1999) Spawning behaviour of Atlantic cod, Gadus morhua: evidence of mate competition, mate choice, and a negative effect of fishing. Can J Fish Aquat Sci 56:97-104

Keckeis H, Bauer-Nemeschkal E, Menshutkin VV, Nemeschkal HL, Kamler E (2000) Effects of female attributes and egg properties on offspring viability in a rheophilic cyprinid, Chondrostoma nasus. Can J Fish Aquat Sci 57:789-796

Kjesbu OS (1989) The spawning activity of cod, Gadus morhua L. J Fish Biol 34:195-206

Kjørsvik E, Lønning S (1983) Effects of egg quality on normal fertilisation and early development of cod, Gadus morhua L. J Fish Biol 23:1-12

Knutsen GM, Tilseth S (1985) Growth, development, and feeding success of Atlantic cod larvae Gadus morhua related to egg size. Trans Am Fish Soc 114:507-511

Kokko H (2001) Fisherian and 'good genes' benefits of male choice: how (not) to distinguish between them. Ecol Lett $4: 322-326$

Köster FW, Hinrichsen HH, Schnack D, St. John MA and 7 others (2003) Recruitment of Baltic cod and sprat stocks: Identification of critical life stages and incorporation of environmental variability and spatial heterogeneity into stock-recruitment relationships. Sci Mar 67(Suppl 1): $129-154$

Marteinsdottir G, Begg GA (2002) Essential relationships incorporating the influence of age, size and condition on variables required for estimation of reproductive potential in Atlantic cod Gadus morhua stocks. Mar Ecol Prog Ser 235:235-256

Marteinsdottir G, Steinarsson A (1998) Maternal influence on the size and viability of Icelandic cod (Gadus morhua L.) eggs and larvae. J Fish Biol 52:1241-1258

Mertz G, Myers RA (1994) Match/mismatch predictions of spawning duration versus recruitment variability. Fish 
Oceanogr 3:236-245

Möllmann C, Köster FW, Kornilovs G, Ludvigs S (2003) Interannual variability in population dynamics of calanoid copepods in the central Baltic Sea. ICES J Mar Sci 219: 220-230

Morrison CM (1990) Histology of the Atlantic cod, Gadus morhua: an atlas. Part 3. Reproductive tract. Can Spec Publ Fish Aquat Sci 110

Panagiotaki P, Geffen AG (1992) Parental effects on size variation in fish larvae. J Fish Biol 41(Suppl B):37-42

Pepin P, Orr DC, Anderson JT (1997) Time to hatch and larval size in relation to temperature and egg size in Atlantic cod (Gadus morhua). Can J Fish Aquat Sci 54(Suppl 1):2-10

Pickova J, Dutta PC, Larsson PO, Kiessling A (1997) Early embryonic cleavage pattern, hatching success, and egglipid fatty acid composition: comparison between two cod (Gadus morhua) stocks. Can J Fish Aquat Sci 54: 2410-2416

Rakitin A, Ferguson MM, Trippel EA (1999) Sperm competition and fertilization success in Atlantic cod (Gadus morhua): effects of sire size and condition factor on gamete quality. Can J Fish Aquat Sci 56:2315-2323

Rakitin A, Ferguson MM, Trippel EA (2001) Male reproductive success and body size in Atlantic cod Gadus morhua L. Mar Biol 138:1077-1085

Reynolds JD, Gross MR (1992) Female mate preference enhances offspring growth and reproduction in a fish, Poecilia reticulata. Proc R Soc Lond B 250:57-62

Rideout RM, Trippel EA, Litvak MK (2004) Paternal effects on haddock (Melanogrammus aeglefinus L.) early life history traits. J Fish Biol 64:695-701

Rosenthal H, Klumpp D, Wiffuhr J (1988) Influence of sperm density and contact time on herring egg fertilization. J Appl Ichthyol 4:79-86

Saillant E, Chatain B, Fostier A, Przybyla C (2001) Parental

Editorial responsibility: Otto Kinne (Editor-in-Chief),

Oldendorf/Luhe, Germany influence on early development in the European sea bass. J Fish Biol 58:1585-1600

Thorsen A, Trippel EA, Lambert Y (2003) Experimental methods to monitor the production and quality of eggs of captive marine fish. J Northw Atl Fish Sci 33:55-70

Tregenza T, Wedell N (2000) Genetic compatibility, mate choice and patterns of parentage: invited review. Mol Ecol 9:1013-1027

Trippel EA (1998) Egg size and viability and seasonal offspring production of young Atlantic cod. Trans Am Fish Soc 127:339-359

Trippel EA (2003) Estimation of male reproductive success of marine fishes. J Northw Atl Fish Sci 33:81-113

Trippel EA, Morgan MJ (1994) Age-specific paternal influences on reproductive success in Atlantic cod (Gadus morhua) of the Grand Banks. ICES Mar Sci Symp 198: 414-422

Trippel EA, Neilson JD (1992) Fertility and sperm quality of virgin and repeat-spawning Atlantic cod (Gadus morhua) and associated hatching success. Can J Fish Aquat Sci 49:2118-2127

Vøllestad LA, Lillehammer T (2000) Individual variation in early life-history traits in brown trout. Ecol Freshw 9: 242-247

Westin L, Nissling A (1991) Effects of salinity on spermatozoa motility, percentage of fertilized eggs and egg development of Baltic cod (Gadus morhua), and implications for cod stock fluctuations. Mar Biol 108:5-9

Wedekind C, Müller R, Spicher H (2001) Potential genetic benefits of mate selection in whitefish. J Evol Biol 14: 980-986

Wedell N, Tregenza T (1999) Successful fathers sire successful sons. Evolution 53:620-625

Winer BJ (1971) Statistical principles in experimental design. McGraw Hill, New York

Submitted: October 18, 2004; Accepted: June 24, 2005

Proofs received from author(s): November 1, 2005 